\title{
An Empirical Study on the Tax Policy to Promote the Development of Urbanization
}

\author{
Xiao-Feng Zhang \\ School of Public Finance and Administration, Harbin University of Commerce, No. \\ 1 Xuehai Street Songbei Harbin City Heilongjiang Province 150028, China \\ zhxf928@163.com
}

\begin{abstract}
New urbanization is an important engine of future economic development, how to use the powerful tax policy to facilitate this process, is particularly important. Select the 1991-2013 tax income and urbanization rate in China, the empirical research on the tax policy to promote the development of urbanization. The establishment of the VAR model, through the stationary test of model variables, lag selection and construction, stationarity test, cointegration test, model test, and the establishment of VEC model, a detailed analysis of the impulse response function. The existence of long-term cointegration relationship of tax revenue and the rate of urbanization, urbanization and development of tax policy to maintain long-term internal consistency, the importance of urbanization tax policy junction has incentive theory.
\end{abstract}

Keywords: Urbanization, Tax policy, VAR

\section{Data selection and model construction}

\subsection{Data selection}

To study the influence of urbanization development tax policy, tax policy and easy to quantify the important quantitative selection of tax revenue to reflect the income, we selected the quantitative data of tax revenue of our country 1991-2013, Ln (TR) expressed in the rate of urbanization, the main reference is the method of Song Yuanliang and Xiao Weidong, with the town population proportion of the total population to measure the level of urbanization, the selection of 1991-2013 national urbanization rate data, using Ln (UR) to express. The data for the logarithm can eliminate the heteroscedasticity to a certain extent, and highlight where elastic significance.

\subsection{Model construction}

Vector autoregression (VAR) refers to the same variable equal right of each equation in the system, and the right side variables include all lagged values of endogenous variables. VAR model to function variables for each endogenous system as the lag of all endogenous variables in the system of value to construct the model, thus the single variable regression model extended to multivariate time the sequence of variables consisting of vector autoregressive model. The need for the system in each endogenous variable of all endogenous

Article history:

Received (August 14, 2016), Review Result (October 17, 2016), Accepted (November 15, 2016) 
variables lagged value function to avoid the modeling problem of structure modeling method, we establish the general expression for the VAR model:

$$
Y_{t}=A_{1} Y_{t-1}+A_{2} Y_{t-2}+\ldots+A_{n} Y_{t-n}+B X_{t}+\varepsilon_{t}
$$

$Y_{t}$ is a column vector variable, ${ }^{X t}$ is an exogenous variable vector, $A_{1}, A_{2} \ldots A_{n}$ and $B$ are the coefficient matrix, ${ }^{\varepsilon t}$ is the estimated error vector.

\section{Empirical test}

\subsection{Variable stationary test}

From table 1 can be seen in the two order difference, Ln (TR) and Ln (UR) are stable in $5 \%$ level and $10 \%$ level significantly.

Table 1. Time series Ln (TR) and Ln (UR) stationary test

\begin{tabular}{|c|c|c|c|c|c|}
\hline series & $(\mathrm{c}, \mathrm{t}, \mathrm{k})$ & t-statistic & $\begin{array}{c}5 \% \text { conspicuous } \\
\text { level }\end{array}$ & $\begin{array}{c}10 \% \text { conspicuous } \\
\text { level }\end{array}$ & result \\
\hline $\mathrm{Ln}$ (TR) & $(\mathrm{c}, \mathrm{t}, 0)$ & 2.3126 & -3.0810 & -2.6813 & instability \\
\hline$\triangle \mathrm{Ln} \quad(\mathrm{TR})$ & $(\mathrm{c}, 0,2)$ & -2.4393 & -3.8289 & -3.3629 & instability \\
\hline$\triangle^{2} \operatorname{Ln} \quad(\mathrm{TR})$ & $(0,0,2)$ & -2.9315 & -1.9710 & -1.6037 & stability \\
\hline Ln (UR) & $(\mathrm{c}, \mathrm{t}, 0)$ & 0.3238 & -3.0299 & -2.6552 & instability \\
\hline$\triangle \mathrm{Ln} \quad(\mathrm{UR})$ & $(\mathrm{c}, 0,2)$ & -1.0594 & -3.7332 & -3.3103 & instability \\
\hline$\triangle^{2} \operatorname{Ln} \quad(\mathrm{UR})$ & $(0,0,2)$ & -2.0427 & -1.9628 & -1.6061 & stability \\
\hline
\end{tabular}

\subsection{VAR model selection and construction lag}

We first selected for the 3 order lag period, through the Eviews software that VAR model, VAR model of lag period of choice, can get 5 evaluation statistics, as shown in [Table 2].

Table 2. VAR lag model selection

\begin{tabular}{|c|c|c|c|c|c|c|}
\hline Lag & $\operatorname{LogL}$ & LR & FPE & AIC & SC & HQ \\
\hline 0 & 14.63964 & NA & 0.000706 & -1.579955 & -1.483381 & -1.575010 \\
\hline 1 & 73.13705 & 95.05829 & $7.84 \mathrm{e}-07$ & -8.392131 & -8.102410 & -8.377295 \\
\hline 2 & 83.14627 & 13.76267 & $3.83 \mathrm{e}-07$ & -9.143283 & -8.660415 & -9.118556 \\
\hline 3 & 92.84908 & $10.91566 *$ & $2.04 \mathrm{e}-07 *$ & $-9.856135^{*}$ & $-9.180120^{*}$ & $-9.821517^{*}$ \\
\hline 4 & 95.49853 & 2.318267 & $2.86 \mathrm{e}-07$ & -9.687316 & -8.818153 & -9.642807 \\
\hline
\end{tabular}

As can be seen from the table, 5 evaluation statistics that should establish a 3 order lag model is established in VAR (3) model. Using Eviews software, VAR (3) model:

LNTRt=0.6989LNTRt-1-0.5074LNTRt-2+0.5351LNTRt-3+0.0257LNURt-11.6031LNURt-2+2.9460LNURt-3-1.8921 
LNURt $=-0.1342$ LNTR $\quad \mathrm{t}-1+0.0841 \mathrm{LNTR} \quad \mathrm{t}-2+0.0710$ LNTR $\mathrm{t}-3+1.2691$ LNUR $\mathrm{t}-1-$ 0.5083 LNUR t-2+0.1311LNUR t-3+0.2535

\subsection{VAR model stability test}

Using AR Roots Table function in Eviews software can obtain all eigenvalues of the VAR model, as shown in [Table 3]; using AR Roots Graph function, can obtain the unit circle curve and location map of VAR model all eigenvalues. [Table 3] shows the VAR model all eigenvalues are less than 1 , which is a very stable system.

Table 3. All eigenvalues of the VAR model

\begin{tabular}{|c|l|}
\hline Root & Modulus \\
\hline 0.998750 & 0.998750 \\
\hline$-0.212996-0.955120 \mathrm{i}$ & 0.978581 \\
\hline$-0.212996+0.955120 \mathrm{i}$ & 0.978581 \\
\hline $0.783700-0.480149 \mathrm{i}$ & 0.919092 \\
\hline $0.783700+0.480149 \mathrm{i}$ & 0.919092 \\
\hline-0.172220 & 0.172220 \\
\hline
\end{tabular}

\section{VEC model and impulse response function}

\subsection{VEC model}

According to the analysis, we choose the lag order of 3 and VEC model:

$\mathrm{D}($ LNTR) $\mathrm{t}=-0.4013$ (LNTRt-1-4.7480LNURt-1+7.4578)+0.2013D(LNTRt-1)0.8523D(LNTRt-2)+0.2797D(LNTRt-3)-3.2031D(LNURt-1)-2.3848D(LNURt-2)$1.5310 \mathrm{D}$ (LNURt-3)+0.4652

$\mathrm{D}$ (LNUR) $\mathrm{t}=0.0016$ (LNTRt-1-4.7480LNURt-1+7.4578)-0.14489D(LNTRt-1)0.1198D(LNTRt-2)-0.0144D(LNTRt-3)+0.2467D(LNURt-1)-0.1626D(LNURt-2)0.3694 D(LNUR t-3)+0.0923

\subsection{Impulse response function}

In the VAR model, the $\mathrm{n}$ variables impact not only directly affects the $\mathrm{n}$ variables but also through the lag structure of the VAR model to transfer to other endogenous variables. The impulse response function describes a variable random error impact on the effect of each endogenous variable of current and future periods due to the presence of. The same period correlation between the random error of different equations in VAR will impact the impact of items related to the same period to period not related to the need to construct an orthogonal matrix. 
Response of LNTR to Cholesky

One S.D. Innovations

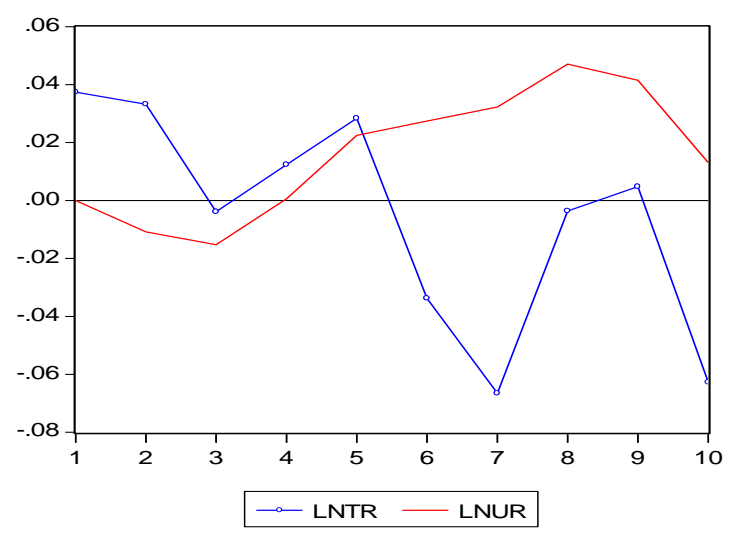

Response of LNUR to Cholesky

One S.D. Innovations

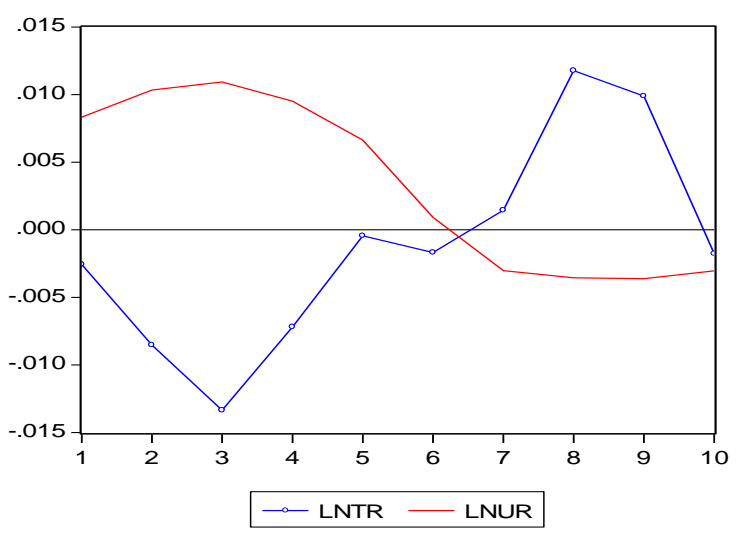

Figure 1. Tax income and urbanization rate on the future of information response

The decomposition is shown in [Figure 1] that describes the tax income and urbanization rate of future information in response to the VEC model.

First, the tax revenue of the urbanization response. A standard for its tax revenue in the first 5 phase difference information of relative ease, from the fifth period, began to react strongly until the seventh phase amplitude reaches the maximum value, the eighth phase of the ninth easing, tenth phase reaction from the impact on a strong performance. Urbanization is the reverse, in the early stage of amplitude changes little impact from the fifth period to the eighth period is significant, reached the peak.

Second, the development of urbanization on the tax revenue response. Urbanization of the six difference information at the beginning of reaction, this process continued until the sixth period, three period lag after gradually leveled off. From the effect of tax revenue is the reverse, in the first period has been reflected the third stage is the most obvious manifestation, the relative ease of the fifth phase to seventh phase reaction, and then the performance is more obvious. It can be seen that there is a close relationship between the development of urbanization and the tax revenue. 


\section{Conclusion and implication}

First, from the basic data, China's tax revenue each year, the rapid growth, in 2013 the national tax revenue reached 110497 billion yuan, representing an increase of $9.84 \%$, exceeded 10 trillion yuan, up 100601 billion yuan, is 36.95 times the tax revenue in 1991, an average annual increase of 4674.19 billion yuan. But the level of urbanization in China is low. In 2013 the urbanization rate was only 53.73\%, far below the level of urbanization in developed countries, but also behind the average level of the world. The development of China's urbanization and city to enter the stationary phase also need a Duan Shijian (relative to the level of urbanization reached above $70 \%$ before entering the stationary phase). Therefore, a great space for the development of China's urbanization the tax policy should play a role in encouraging the development of urbanization.

Second, the existence of a long-term cointegration relationship between tax revenue and the rate of urbanization. With the development of China's economy and the improvement of rural productivity, tax revenues will continue to increase, change the tax system and policy and optimize the scale and structure of tax and urbanization development will maintain longterm internal consistency.

Third, the development of urbanization and the tax policy and the system have a close relationship. On the one hand shall formulate the corresponding tax policy to encourage the sustainable development of China's urbanization; on the other hand, by vigorously promoting the development of urbanization process, to make the optimization of the tax system of our country economic variables in the promotion of science the reasonable and effective distribution of growth of revenue and expenditure. Therefore, our country should improve tax support, play the effect of tax incentives, appropriate adjustment of the corresponding measures, the establishment of the urbanization and the tax policy of "two-way development" of the economy.

Fourth, the importance of urbanization requires an incentive tax policy. Urbanization is an important way of building a new socialist countryside, is an important means to realize a comprehensive well-off society, is the only way which must be passed to realize agricultural modernization, is an important guarantee for the construction of a harmonious society, accelerate the urbanization will become the main driving force of China's economic society the development in the future. But the process of urbanization in our country has a lot of markets itself can not solve the problem, therefore, the government should regulate the tax policy support measures to fully play the role of macro-control of tax policy, at the same time with international standards, comply with the international trend of development, enhance the level of urbanization, play an important role in the economic function of government.

\section{Acknowledgment}

This research was financially supported by the Heilongjiang Social Science Fund Project "Study on the fiscal policies to promote the development of the new-style urbanization in Heilongjiang" (16JYC09) and the Harbin University of Commerce Youth Innovation Talent Support Project "study on fiscal policy innovation and mechanism of the new-style urbanization development" (2016QN003) 


\section{References}

[1] United Nations World Urbanization Prospects: The 1994 Revision [M], New York: United Nations

[2] X.M. Huang and T. Xiao, "The current new town development and taxation problems", Journal of Economic Research, Vol. 6, (2015)

[3] S. Wang and X. Zhang, "To promote the development of urbanization analysis and suggestions of tax policy Chinese", Journal of Administration, vol.9, pp. 87-92, (2015)

[4] C. Long, and Z. Ming, "Study on new towns and support cross regional allocation of labor tax policy", Journal of Local Finance, vol.3, pp. 85-89+96, (2016)

[5] W. Zeps, "Energy consumption in the process of urbanization, environmental management and green tax -- a green endogenous economic growth model”, Journal of Yunnan University of Finance and Economics, vol.2, pp.49-61, (2016)

[6] C. Yu, "Fiscal decentralization, the central tax grab expansion", Journal of Research on Financial and Economic Issues and Local Government Debt, vol.9, pp.71-76, (2016) 